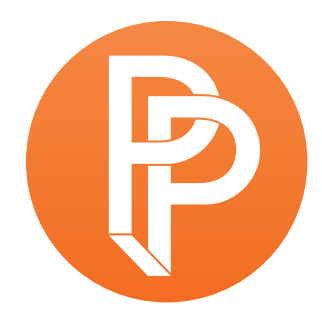

PERFORMANCE

PHILOSOPHY

\title{
REVIEW BAMBOOZLED: ARCHIVAL AFFECTS
}

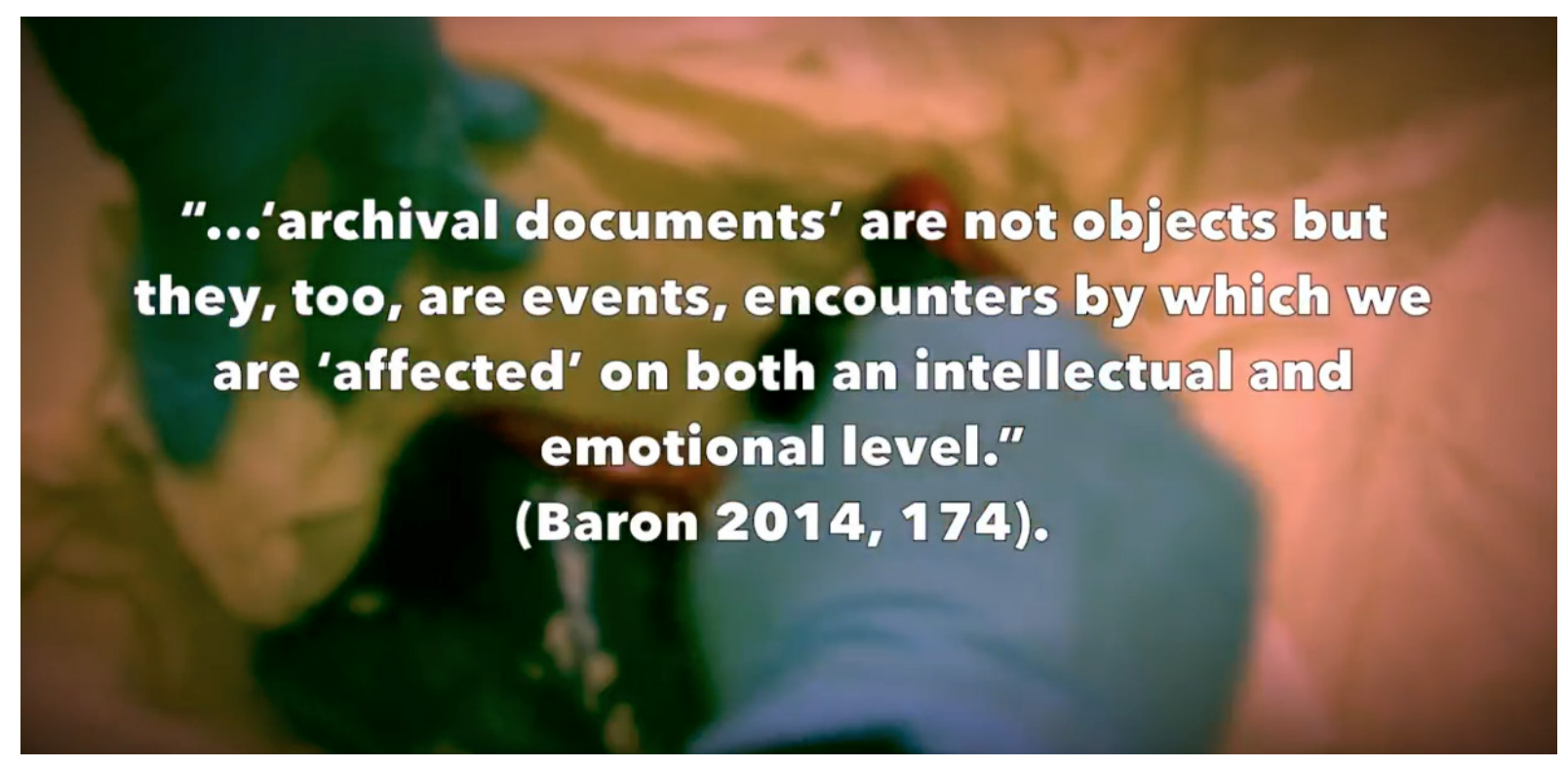

1 Watch this ReView here: https://youtu.be/Anva6TSKtOI 


\section{TIME CODES:}

1. A Definition of Affect - 00:00

2. A Bamboozled Affect, Or The First Time the Author Watched Bamboozled - 00:26

3. Capturing Another Affective Moment- 02:25

4. Going to and Encountering the Archive - 03:33

5. The Gift of the Archive - The Lester Glassner African American Experience Collection Arrives - 06:31

6. Opening up Archives / Opening up Affects - 10:03

7. The Story behind the Lester Glassner Collection - 16:20

8. Feelings, Emotions, and Affects in the Archive ("I just feel really sad") - 18:00

9. A Summary of Bamboozled - 24:01

10. Mrs. Drummond - 26:43

11. Going Through the Box, Part I: A Performance of Archival Labor - 27:28

12. Can't I Just Smash This to the Ground?: Archival Affective Tensions - 33:37

13. Of Glassner/Bamboozled's Archival Impulse - 37:03

14. Going Through the Box, Part II: Archival Labors Uninterrupted - -39:52

15. The Archival Laboring Body Affected - 46:31

16. The Last Archival Object in the Box / Conclusions - 49:49

17. Credits / Works Cited - 51:58

\section{Works Cited}

\section{ARCHIVES}

The Lester Glassner African American Experience Collection. Archives \& Special Collections Department. E. H. Butler Library. SUNY Buffalo State.

\section{WORKS CITED}

Bamboozled. 2000. Directed by Spike Lee. New Line Home Entertainment, 2001. DVD.

Baron, Jaimie. 2014. The Archive Effect: Found Footage and the Audiovisual Experience of History. New York: Routledge.

Bernstein, Robin. 2011. Racial Innocence: Performing American Childhood from Slavery to Civil Rights. New York: New York University Press.

Glassner, Lester, and Brownie Harris. 1981. Dime-Store Days. New York: Penguin.

Harris, Verne. 2002. "The Archival Sliver: Power, Memory, and Archives in South Africa." Archival Science 2 (1-2): 6386. ProQuest Central. https://doi.org/10.1007/BF02435631

Lumiere, Samuel. ca. 1921. Bert Williams \#12. Photograph. Retrieved from the Library of Congress. Accessed February 28, 2018. https://www.loc.gov/item/2014645145/.

Nyong'o, Tavia. 2002. "Racial Kitsch and Black Performance." The Yale Journal of Criticism 15 (2): 371-91. https://doi.org/10.1353/yale.2002.0021 
Pilgrim, David. 2005. "The Garbage Man: Why I Collect Racist Objects." Jim Crow Museum of Racist Memorabilia. Ferris State University. Last Modified 2012. Accessed September 30, 2017. https://ferris.edu/HTMLS/news/jimcrow/collect.htm.

Plutchik, Robert. 2001. "The Nature of Emotions." American Scientist 89 (4): 344-350. https://doi.org/10.1511/2001.4.344

Shouse, Eric. 2005. "Feeling, Emotion, Affect." M/C Journal 8 (6). Accessed January 24, 2017. http://journal.mediaculture.org.au/0512/03-shouse.php.

Strobridge \& Co. Lith and Wm. H. West's Big Minstrel Jubilee. 1900. Wm. H. West's Big Minstrel Jubilee. Photograph. New York: Strobridge \& Co. Lith. Retrieved from the Library of Congress. Accessed February 28, 2018. https://www.loc.gov/item/2014637077/.

Waskul, Dennis, and Phillip Vannini. 2016. "The Performative Body: Dramaturgy, the Body, and Embodiment." In The Drama of Social Life: A Dramaturgical Handbook, edited by Charles Edgeley, 197-210. London: Routledge. Original edition, Ashgate Publishing, 2013.

\section{MUSIC}

MacLeod, Kevin (incompetech.com). Infados. Licensed under Creative Commons: By Attribution 3.0 License http://creativecommons.org/licenses/by/3.0/.

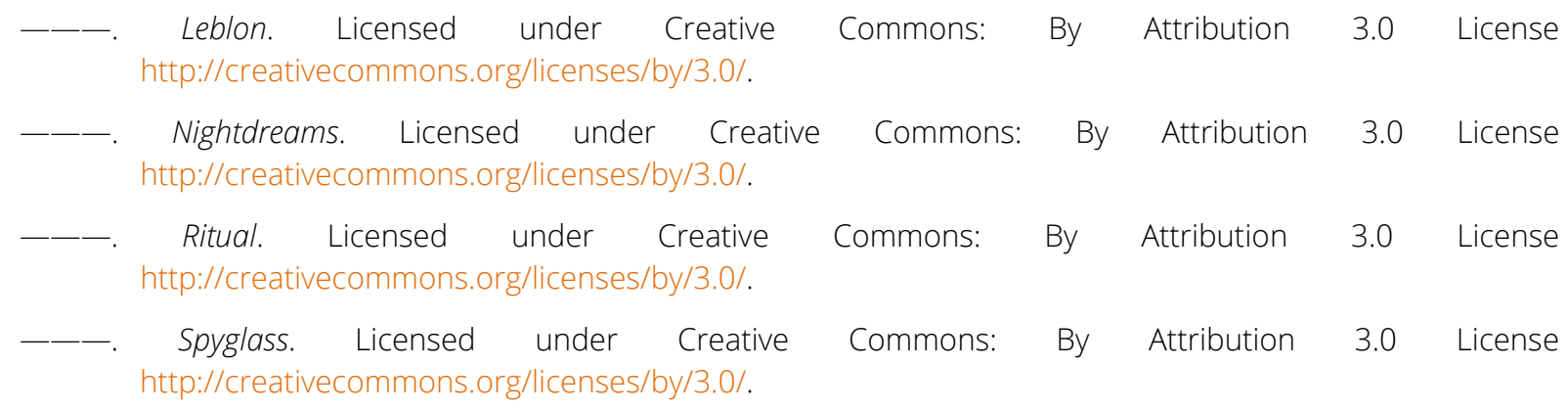

Dan-O. Ghost Island - EDM Trap Instrumental. DanoSongs.com.

Dan-O. Ghost Island - EDM Trap Vocals. DanoSongs.com.

\section{Biography}

Scholartist* Dr. Amma Y. Ghartey-Tagoe Kootin (a.k.a. Dr. Amma) creates artistic works based on archival research for the stage and screen and writes about late-19th-century black performance. An assistant professor with a joint appointment in the Institute for African American Studies and the Department of Theatre and Film Studies at the University of Georgia, she bridges the worlds of academia and arts/entertainment having worked for National History Day, Inc. and A\&E® Networks/The History Channel. Her current projects are an historical musical about black performers in the 1901 Pan-American Exposition entitled AT BUFFALO, and a book about the relation between laughter and the American slave experience, entitled Laughing after Slavery: The Performances and Times of Laughing Ben Ellington.

*A term credited to performance studies colleagues Joseph Shahadi and Mila Aponte-Gonzalez.

(c) 2018 Amma Y. Ghartey-Tagoe Kootin

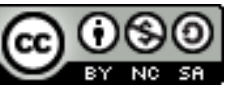
Except where otherwise noted, this work is licensed under a Creative Commons AttributionNonCommercial-ShareAlike 4.0 International License. 